Received 26.09.2017

Reviewed 19.11.2017

Accepted $\quad 02.02 .2018$

A - study design

B - data collection

C - statistical analysis

D - data interpretation

$\mathbf{E}$ - manuscript preparation

F - literature search

\section{Condition and population structure of the round goby (Neogobius melanostomus Pallas, 1811) in Szczecin Lagoon in 2010-2014}

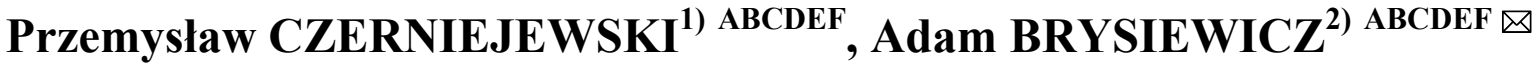

\author{
${ }^{1)}$ West Pomeranian University of Technology, Faculty of Food Sciences and Fisheries, Facility of Fisheries Management, \\ Szczecin, Poland; e-mail: przemyslaw.czerniejewski@zut.edu.pl \\ ${ }^{2)}$ Institute of Technology and Life Sciences, Kuyavian-Pomeranian Research Centre, Czesława 9, 71-504 Szczecin, \\ Poland; e-mail: a.brysiewicz@itp.edu.pl
}
For citation: Czerniejewski P., Brysiewicz A. 2018. Condition and population structure of the round goby (Neogobius melanostomus Pallas, 1811) in Szczecin Lagoon in 2010-2014. Journal of Water and Land Development. No. 37 p. 49-55. DOI: 10.2478/jwld-2018-0024.

\begin{abstract}
The round goby (Neogobius melanostomus Pallas, 1811) is one of the most invasive fish species in the world, including Poland. 300 fish of this species were collected in the waters of Szczecin lagoon between 2010 and 2014 and examination of the size, sex and age structures of the population and of the condition of the fish was performed. Total length and standard length of all the collected fish amounted to $149.2 \mathrm{~mm}( \pm 42.21)$ and $128.1 \mathrm{~mm}( \pm 38.65)$, respectively. The age structure of the fish consisted of nine generations, with clear prevalence of the fish aged 3+ and 4+. Mean values of condition factors for the whole fish sample amounted to 0.20 $( \pm 0.02)$. However, no statistically significant differences in particular years were observed (ANOVA, $p>0.05$ ), but the condition of the fish between 2010 and 2011 was slightly higher than between 2013 and 2014. The obtained results indicate that the Szczecin Lagoon environment provides this species with favourable living conditions and it can be stipulated that the quantity of individuals of this fish species will increase.
\end{abstract}

Key words: age of fish, gender structure, length structure, Neogobius melanostomus, round goby, Szczecin Lagoon

\section{INTRODUCTION}

The natural habitat for the round goby (Neogobius melanostomus Pallas, 1811) is the area of the Ponto-Caspian basin where it resides in the littoral zone of the Black Sea and the Sea of Azov as well as in rivers flowing into them and in areas of the Sea of Marmara and the Caspian Sea [BERG 1965; KOTTELAT, FREYHOFF 2007; SVETOVIDOV 1964]. Its intensive invasion is indicated by the fact that currently the round goby can also be found in the Baltic Sea and in the Great Lakes of North America [PHILLIPS et al. 2003; SAPOTA 2005]. In the former water body, precisely in Gdansk Bay, the fish was first observed in 1990 [SKÓRA, STOLARSKI 1996]. According to SKÓRA [1997], the age of the collected round goby individuals was estimated at 3-4 years so they had been residing in the waters since around 1987. Presumably, the spawn or the fry of this species could have reached our sea with ballast waters of longdistance ships coming from areas of the Black Sea and the Caspian Sea or could have travelled into the Baltic Sea using natural connections of rivers and canals: The Dnieper River, the Prypiat River, the Bug River and the Vistula River or the Volga River and using canals through Lake Ladoga. However, due to the fact that the round goby, as a pelagic species, is not a good swimmer, it is difficult to imagine it cover- 
ing such a distance unaided travelling the majority of the distance against the current. Having invaded the littoral zones of Puck Bay and Gdansk Bay, the round goby began to spread westwards and reached the shores of Germany and Sweden [MARSDEN et al. 1997]. Round gobies were first caught in the Oder estuary at the beginning of the $21^{\text {st }}$ century in the Bay of Pomerania [SAPOTA 2005] and from 2003 juvenile individuals and from 2006 adult individual began to appear in the catch in the German part of Szczecin Lagoon [WINKLER 2006]. The first documented observations of this species in the Polish part of Szczecin Lagoon were made in 2009 by CzUGAŁA and WoŹNICZKA [2010], reporting the presence of the fish in fishermen's catches. Currently, the round goby is also observed in the Oder River on the German side near Schwedt [SCHOMAKER, WOLTER 2014] and on the Polish side near Widuchowa (our own source). Its further invasion appears to be certain. This resembles the occurrence of the invasive pumpkinseed in the waters of Międzyodrze which today is commonly found in the ichthyofauna of the waters in the Valley of the Lower Oder [DĄBKOwSKI et al. 2017]. Although the round goby has been present in Szczecin Lagoon for almost a decade, so far a detailed description of its population has not been prepared. This information is important due to the negative influence of this invasive species on native fish and invertebrate species consisting in consumption of their spawn and juvenile individuals and in competition for food supplies and habitats [SAPOTA 2005].

The aim of the present work was to assess the condition of the round goby population in Szczecin Lagoon, including the length and age of the fish and their condition in 2010-2014.

\section{MATERIAL AND METHODS}

During fish catches conducted in five research seasons (2010-2014) using such equipment as fyke nets from June to November in Szczecin Lagoon (Fig. 1), 300 round goby (Neogobius melanostomus) individuals were collected. The quantity of the collected fish in each research year and the number of fishing nets used in the catches are given in Table 1. All the collected fish were subjected to biological analysis to determine their total length and standard length using a digital calliper (Twin-cal IP 40, Tesa France S.A.S) with accuracy to $0.1 \mathrm{~mm}$ as well as individual weights $(W)$ using Axis digital scales (Radwag, Poland) with accuracy to $0.1 \mathrm{~g}$. The sex of the fish was determined on the basis of the morphological structure of urogenital papilla [KORNIS et al. 2012].

The well-known equation given by Fulton $(K)$ was used to assess condition of the fish [FROESE 2006]:

$$
K=\frac{100 W}{T L^{3}}
$$

Where: $W=$ total weight of the fish $(\mathrm{g}) ; T L=$ total length of the fish (mm).

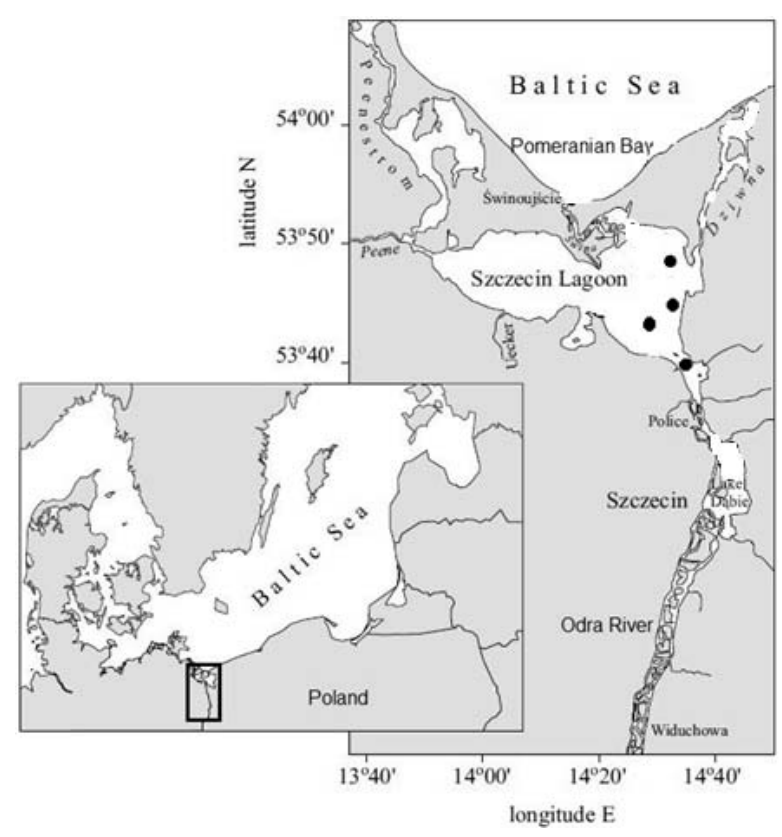

Fig. 1. Fishing grounds for the round goby (Neogobius melanostomus) (marked as black dots) between 2010 and 2014; source: own elaboration

Table 1. The number of individuals of the round goby ( $\mathrm{Ne}$ ogobius melanostomus) and fishing nets used to catch it in Szczecin Lagoon between 2010 and 2014

\begin{tabular}{|c|c|c|}
\hline Year & $\begin{array}{c}\text { The number } \\
\text { of fish caught }\end{array}$ & $\begin{array}{c}\text { Number } \\
\text { of used fyke nets }\end{array}$ \\
\hline 2010 & 31 & 16 \\
\hline 2011 & 42 & 12 \\
\hline 2012 & 57 & 8 \\
\hline 2013 & 82 & 4 \\
\hline 2014 & 88 & 4 \\
\hline Subtotal & 300 & 44 \\
\hline
\end{tabular}

Source: own elaboration.

Otoliths were used to determine age. Age was read from annual rings on otoliths (right and left sides of the otolith) in compliance with a method suggested by GÜMÜș and KURT [2009].

The measurement results were analysed statistically, calculating e.g. the mean value $(\bar{x})$, standard deviation $(S D)$, ranges, their distribution in size classes suing Statistica 12.0 PL (StatSoft, Poland). In the case of comparisons of mean values between fish sexes, $t$-Student test was used, earlier evaluating normality of variables distribution using Kolmogorov-Smirnov test and the equality of variances was controlled using Levene's test. In the case of numerous variables, a one-way variance analysis (ANOVA) was used. Distribution normality in each group was checked using Shapiro-Wilk test whereas the equality of variance was assessed using Levene's test. Tukey's HSD test was used as a post hoc test [SOKAL, ROHLF 2012].

\section{RESULTS}

The round goby (Neogobius melanostomus) from Szczecin Lagoon was caught using trapping equip- 
ment (fishing nets) placed in different parts of this water body at the depth below $3.5 \mathrm{~m}$. The bottom was sludgy or sludgy and sandy with a bigger content of sand where the nets were placed. The fishing nets placed in the latter bottom type caught $78.9 \%$ of the round goby individuals.

Altogether, between 2010 and 2014, 300 round goby individuals were caught among which the greatest number of fish (over 80 individuals per year) was caught between 2013 and 2014 using a smaller number of fishing nets than between 2010 and 2011, which indicates a greater concentration of its population. The difference in the number of fishing nets used in each year resulted from the fact that some fishing units from which the fish was collected did not perform catches using fishing nets. Taking into account all the fish, a similar proportion of males and females $(1: 1)$ was observed. However, the distribution of the sexes in each year was characterised by a great disproportion (Fig. 2). Females prevailed between 2010 and $2012(54.5-64.5 \%)$ whereas the number of males increased in consecutive years $(54.55-54.88 \%)$.

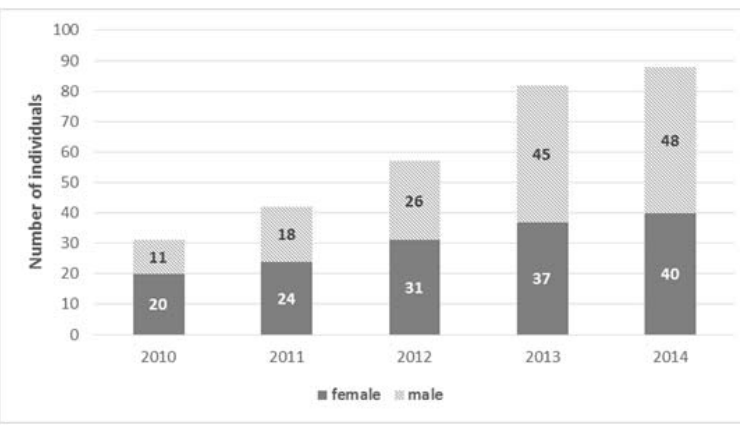

Fig. 2. Sex structure and the number of individuals of the round goby (Neogobius melanostomus) caught in Szczecin Lagoon between 2010 and 2014; source: own study
The range of the unit weight of the round goby amounted to 6.6-146.2 $\mathrm{g}$ (mean $68.8 \mathrm{~g} \pm 41.23$ ). Having divided the data into sexes, the statistical analysis of the mean weight demonstrated a statistically significant difference (test $t, t=2.9865, p=0.003$ ) between males and females. The males were characterised by a greater mean unit weight $(68.6 \mathrm{~g} \pm 39.95$, ranging from 10.4 to $146.2 \mathrm{~g}$ ) in comparison to the females $(64.8 \mathrm{~g} \pm 39.21$, ranging from 6.6. to $124.2 \mathrm{~g})$.

Total length $(T L, \mathrm{~mm})$ and standard length ( $S L$, $\mathrm{mm})$ of all the collected fish amounted to $149.2 \mathrm{~mm}$ $( \pm 42.21 \mathrm{~mm})$ and $128.1 \mathrm{~mm}( \pm 38.65 \mathrm{~mm})$, respectively. However, statistically significant differences between the males and females were observed. The males were characterised by a statistically greater mean total length (test $t, t=3.2426, p=0.001$ ) and standard length (test $t, t=3.1653, p=0.002$ ) (156.3 $\mathrm{mm} \pm 39.65$ and $132.6 \mathrm{~mm} \pm 34.65$, respectively) in comparison to the females (147.2 $\mathrm{mm} \pm 40.35$ and $125.9 \mathrm{~mm} \pm 33.65 \mathrm{~mm}$, respectively). The correlation between the two lengths ( $T L$ and $S L$ ) of the round goby can be expressed as follows: $S L=0.8371 T L+$ $1.7432(R=0.942)$.

Having divided the fish into fishing years, excluding 2010 (probably due to too small a number of the fish samples), statistically significantly greater lengths ( $T L$ and $S L$ ) and unit weights of the males in comparison to the females (test $t, p<0.05$ ) were observed (Tab. 2).

Moreover, it was observed that during the first years of fishing (2010-2012) the mean lengths (TL and $S L$ ) and unit weights of the round goby were statistically significantly greater in comparison to 20132104 (ANOVA, $p<0.05$ ). For example, in 210 the mean lengths for the fish not divided by sex amounted to $T L=154.9 \mathrm{~mm}( \pm 39.84), S L=130.6 \mathrm{~mm}( \pm 31.54)$ and the unit weight was $71.9 \mathrm{~g}( \pm 39.82)$ whereas in

Table 2. Total body length $(T L, \mathrm{~mm})$, standard body length $(S L, \mathrm{~mm})$, unit weight $(W, \mathrm{~g})$ and condition $(K)$ of the round goby (Neogobius melanostosmus) caught in 2010-2014

\begin{tabular}{|c|c|c|c|c|c|c|c|c|c|}
\hline \multirow{2}{*}{$\begin{array}{l}\text { Year } \\
\text { of } \\
\text { fishing }\end{array}$} & \multirow[b]{2}{*}{ Sex } & \multicolumn{2}{|c|}{ Unit weight } & \multicolumn{2}{|c|}{ Total length } & \multicolumn{2}{|c|}{ Standard length } & \multicolumn{2}{|c|}{ Condition } \\
\hline & & $\begin{array}{c}\text { average } \\
W \pm S D \text {, g }\end{array}$ & $\begin{array}{c}\text { range } \\
W, \mathrm{~g}\end{array}$ & $\begin{array}{c}\text { average } \\
T L \pm S D, \mathrm{~mm}\end{array}$ & $\begin{array}{c}\text { range } \\
T L, \mathrm{~mm}\end{array}$ & $\begin{array}{c}\text { average } \\
S L \pm S D, \mathrm{~mm}\end{array}$ & $\begin{array}{c}\text { range } \\
S L, \mathrm{~mm}\end{array}$ & $\begin{array}{c}\text { average } \\
K \pm S D\end{array}$ & $\begin{array}{c}\text { range } \\
K \\
\end{array}$ \\
\hline \multirow{3}{*}{2010} & female & $70.7 \pm 36.81$ & $8.6-124.2$ & $153.7 \pm 37.04$ & $82.6-205.2$ & $129.6 \pm 31.17$ & $70.8-172.5$ & $.20 \pm 0.01$ & $18-0.23$ \\
\hline & male & $72.3 \pm 39.71$ & $2.6-146.2$ & $155.3 \pm 39.47$ & $101.5-216.3$ & $131.5 \pm 30.65$ & $8.6-184.3$ & $19 \pm 0.01$ & $19-0.22$ \\
\hline & together & $\mathbf{7 1 . 9} \mathbf{9}^{\mathbf{}} \pm 39.82$ & $8.6-146.2$ & $\mathbf{1 5 4 . 9}^{\mathbf{a}} \pm 39.84$ & $82.6-216.3$ & $\mathbf{1 3 0 . 6}^{\mathbf{a}} \pm 31.54$ & $70.8-184.3$ & $\mathbf{0 . 2 0} \pm 0.01$ & $0.18-0.23$ \\
\hline \multirow{3}{*}{2011} & female & $71.8 * \pm 26.95$ & $15.8-106.2$ & $154.8 * \pm 36.89$ & $08.1-195.6$ & $128.7 * \pm 28.96$ & $91.9-$ & $0.20 \pm 0.02$ & $17-0.22$ \\
\hline & male & $75.6 * \pm 27.81$ & $18.2-126.5$ & $158.2 * \pm 38.62$ & $112.5-206.2$ & $132.5 * \pm 32.56$ & $95.5-174.5$ & $.20 \pm 0.01$ & $18-0.21$ \\
\hline & together & $\mathbf{7 3 . 8}^{\mathbf{a}} \pm 28.21$ & $15.7-1$ & $\mathbf{1 5 6 . 6}^{\mathbf{a}} \pm 38.96$ & 108 & $\mathbf{1 3 1 . 2}^{\mathbf{a}} \pm 30.11$ & 91. & 0.02 & $7-0.22$ \\
\hline \multirow{3}{*}{2012} & female & $66.4 * \pm 32.56$ & $8.2-96.8$ & $149.6 * \pm 35.62$ & $84.2-189.9$ & $126.1 * \pm 31.89$ & 72.1 & $0.19 \pm 0.01$ & $.18-0.22$ \\
\hline & male & $72.1 * \pm 33.42$ & $18.5-122.3$ & $156.8 * \pm 36.51$ & $113.5-204.2$ & $135.6 * \pm 30.65$ & 96.5 & $0.20 \pm 0.02$ & $0.17-0.22$ \\
\hline & togeth & $\mathbf{7 1 . 3} \mathbf{3}^{\mathrm{a}} \pm 34.65$ & $8.2-122.3$ & $\mathbf{1 5 4 . 2}^{\mathrm{a}} \pm 36.76$ & -204.2 & $\mathbf{1 3 2 . 5}^{\mathbf{a}} \pm 31.98$ & 72. & $\mathbf{0 . 1 9} \pm 0.02$ & $0.17-0.22$ \\
\hline \multirow{3}{*}{2013} & female & $56.3 * \pm 31.56$ & $7.8-112.6$ & $143.2 * \pm 39.98$ & $2-201.5$ & $119.5 * \pm 32.15$ & 54.6 & $0.19 \pm 0.02$ & $0.17-0.22$ \\
\hline & male & $69.2 * \pm 33.26$ & $10.6-116.9$ & $152.1 * \pm 38.26$ & $95.6-200.2$ & $129.9 * \pm 31.05$ & $81.4-168.1$ & $0.19 \pm 0.01$ & $0.18-0.22$ \\
\hline & togetl & $\mathbf{6 2 . 4}^{\mathbf{b}} \pm 34.36$ & $7.8-1$ & $\mathbf{1 4 6 . 9}^{\mathbf{b}} \pm 39.86$ & & $\mathbf{1 2 6 . 5}^{\mathbf{b}} \pm 32.11$ & 54.6 & 0.02 & $.17-0.22$ \\
\hline \multirow{3}{*}{2014} & female & $52.9 * \pm 32.12$ & $6.6-104.6$ & $141.3 * \pm 39.46$ & $56.5-194.6$ & $119.4 * \pm 32.05$ & $48.6-166.5$ & $0.19 \pm 0.01$ & $0.18-0.20$ \\
\hline & male & $64.2 * \pm 34.86$ & $10.4-118.2$ & $149.0 * \pm 36.45$ & $95.2-202.2$ & $126.4 * \pm 31.26$ & $85.4-172.1$ & $0.20 \pm 0.01$ & $0.18-0.21$ \\
\hline & together & $\mathbf{6 3 . 2}^{\mathbf{b}} \pm 35.11$ & 6.6-118.2 & 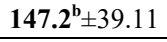 & 56.2-202.2 & $\mathbf{1 2 4 . 1}^{\mathbf{b}} \pm 32.01$ & 48.6-172.1 & $\mathbf{0 . 1 9} \pm 0.01$ & $0.18-0.21$ \\
\hline
\end{tabular}

Explanations: * statistically significant differences between sex (test $t, p<0.05),{ }^{\mathrm{a}, \mathrm{b}}=$ the average for the trials of individual years, without the division into sex, marked with the same letter do not differ significantly in terms of statistics (ANOVA, test Tukeya, $p<0.05$ ). Source: own study. 
2014 they were $147.2 \mathrm{~mm}( \pm 39.11)$ and $124.1 \mathrm{~mm}$ $( \pm 32.01)$, respectively, and $63.2 \mathrm{~g}( \pm 35.11)$ - Table 2 .

Between 2010 and 2014, individuals in classes from 120.1 to $180 \mathrm{~mm}$, which constituted $62.33 \%$ of all the fish, prevailed in the lengths of the collected fish. However, the analysis of the distribution of the lengths in each year allows us to claim that between 2010 and 2011 bigger fish in length classes of 140.1$200 \mathrm{~mm}$ prevailed, and they constituted $77.4 \%$ and $71.4 \%$, respectively, of the whole catch from the given year. However, between 2013 and 2014, a clear prevalence of smaller fish in classes of 100.1-180.0 $\mathrm{mm}$ was observed. The fish in the aforementioned classes constituted $78.0 \%$ and $73.9 \%$ of the fish, respectively (Fig. 3). It is worth noting that between 2013 and 2014 the fish that was caught belonged to all nine total length classes, but in 2010 and $2012 \mathrm{sev-}$ en classes and in 2011 only six classes. These years did not feature individuals with the total length below $80 \mathrm{~mm}(T L)$.

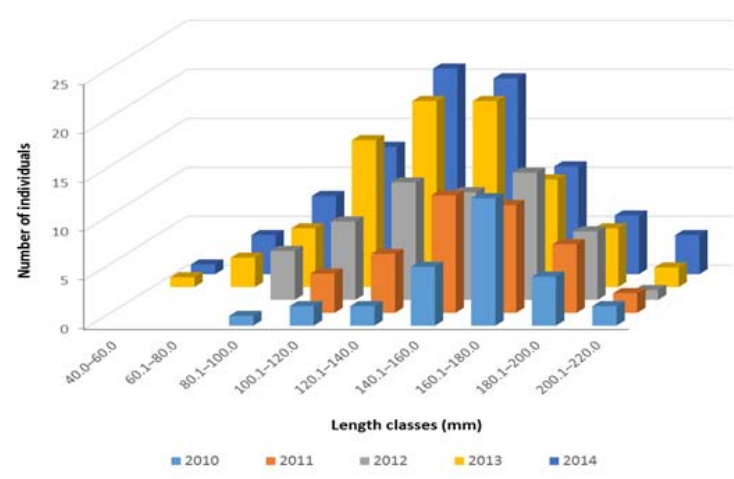

Fig. 3. Length structure for the round goby (Neogobius melanostomus) in Szczecin Lagoon between 2010 and 2014; source: own study

The condition of the fish was evaluated on the basis of Fulton's condition factor $(K)$. The mean values of condition factors for the whole fish sample amounted to $0.20 \pm 0.02$, but no statistically significant differences between the females (mean $0.19 \pm 0.02$ ) and males (mean $0.20 \pm 0.02$ ) were observed (test $t$, $t=1.7566, p=0.080$ ). Also, no statistically significant difference between the condition of the fish in each year was observed (ANOVA, $p>0.05$ ). However, the condition of the fish between 2010 and 2011 appeared to be slightly higher $(K=0.2)$ in comparison to $2013-2014(K=0.19)$.

All the studied fish can be classified for six age groups (from $1+$ to $6+$ ), but the prevailing groups were $3+$ which constituted $34.7 \%$ (104 individuals) and $4+(25.33 \%, 76$ individuals $)$. A disproportion in the age structure between individual fishing periods was observed. In 2010-2011 individuals aged from $2+$ to $6+$ were observed whereas in the other years (from $1+$ to $6+$ ) - Figure 4.

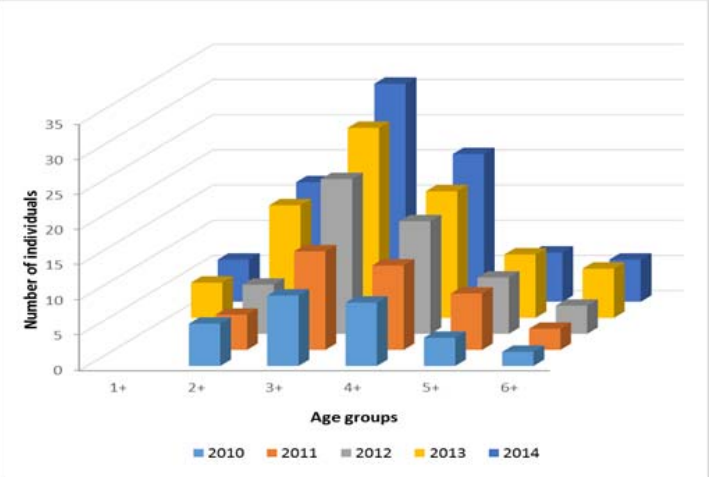

Fig. 4. Age structure for the round goby (Neogobius melanostomus) in Szczecin Lagoon in each year of studies; source: own study

\section{DISCUSSION}

The round goby (Neogobius melanostomus) was first caught in the Baltic Sea in 1986 in Gdansk Bay [SKÓRA, STOLARSKI 1993] and from 1994 it was observed almost in the whole of the Polish part of Gdansk Bay, including Puck Bay [KUCZYŃSKI 1995]. In the 1990s the first individuals appeared in coastal lakes: Łebsko and Gardno in the Słowiński National Park [CIEPIELEWSKI, HoRNATKIEWICZ-ŻBIK 2003]. The round goby was observed in the Polish part of the Vistula Lagoon in 1999 and later it also appeared in the Russian part [BOROWSKI 1999]. The round goby was observed in the Vistula River as high as in the area of Świecie (130 km from its estuary) [KOSTRZEWA, GRABOWSKI 2003]. In 2003 the round goby could be caught with a fishing rod in the distributary channel of the Dziwna River in Dziwnów [SKÓRA 2004]. In 2009 adult individuals of this species were first observed in the Polish part of Szczecin Lagoon [CZUGAŁA, WoźNICZKA 2010] and, taking into account their lengths, they must have been there for at least five years. This is confirmed by observations of occurrence of juvenile individuals of the round goby in the German part of Szczecin Lagoon made by WINKLER [2006]. It is difficult to explicitly determine whether the population of the round goby comes directly from the waters of Gdansk Bay (situated approx. $450 \mathrm{~km}$ from Szczecin Lagoon) or from the waters of the coastal region of Germany. According to WINKLER [2006], the round goby appeared in Rugen, an island situated approx. $120 \mathrm{~km}$ from Szczecin Lagoon, in 1998. Assuming that the population of the round goby in the Oder estuary originated directly from Gdansk Bay, its expansion rate amounts to 32 $\mathrm{km} \cdot \mathrm{year}^{-1}$. The value is extremely similar to the expansion rate for the population in the coastal regions of Denmark [AzOUR et al. 2015], but significantly lower than for populations from the Great Lakes of North America according to GROSHOLZ [1996]. Expansion of the round goby is supported by its high tolerance of a wide range of environmental conditions, its aggressive behaviour, early puberty and high 
fertility as well as the possibility of reproduction several times a year [SAPOTA 2005].

In the Baltic Sea, populations of this species reside in shallow places at the depth below $20 \mathrm{~m}$ [KULLANDER, DELLING 2012] although some habitats can even be found at the depth of $50-60 \mathrm{~m}$ [KotTelat, FreyHofF 2007]. This indicates that the whole bottom of Szczecin Lagoon can be penetrated by this species and these habitats are in danger of the effect of this invasive fish. Unfortunately, it is difficult to accurately determine the concentration of the round goby in Szczecin Lagoon. However, it appears to be significantly lower than in Gdansk Bay (over 3.4 individuals per $\mathrm{m}^{2}$ ) [SAPOTA, SKÓRA 2005] or in the waters of North American lakes (over 50 individuals per $\mathrm{m}^{2}$ ) [MARSDEN et al. 1997].

The proportion of males and females among the collected fish between 2010 and 2014 in Szczecin Lagoon was 1:1 whereas in numerous other water bodies in non-native populations males prevail [GUTOWSKI, FOX 2011]. This may result from various fishing methods, periods of fishing and the degree of invasion of a new water body. According to [BRANDNER et al. 2013], during the first stage of populating a water body, females, responsible for excessive spawning, prevail whereas in the final stages of expansion the contribution of males increases. Similar changes in the number of females (they prevail in the first years of studies) and males (they prevail in 20132014) were observed in Szczecin Lagoon. According to laboratory tests conducted by MARENTETTE $e t$ al. [2011], the greater number of the round goby males results from their greater motility in the final stage of invasion.

The maximum length achieved by the round goby in Szczecin Lagoon amounts to $216.3 \mathrm{~mm}$, but the males achieve greater lengths than the females. The values are higher than those given for the Danube basin [GRULA et al. 2012], but do not differ much from the values obtained for non-native populations of North American waters [MARSDEN et al. 1997], but they are significantly lower, especially in the case of males from the waters of the natural coverage [BERG 1965]. For example, in not-native Danube populations of the round goby, the maximum standard length $(S L)$ of the round goby amounted to $153 \mathrm{~mm}$ (Slovakia), $150 \mathrm{~mm}$ (Austria) [GRULA et al. 2012; WIESNER 2005] whereas in the waters of the natural coverage, the standard length of the fish reaches $250 \mathrm{~mm}$ [BERG 1965]. Probably, it does not result from the shorter life cycle of individuals from non-native populations, because five and six-year-old individuals were observed both in waters of the natural coverage and in waters colonised by the round goby [BERG 1965; SoKOŁOWSKA, Fey 2011]. Also in Szczecin Lagoon, despite the prevalence of fish aged $3+$, fish aged $6+$ (the maximum age) was observed. It has to be emphasised here that in each year of the studies of populations of the round goby a downward trend in the mean length and weigh of the caught fish was observed. It could result from changes in the population occurring during their invasion connected with changes in concentration and food competition [BøHN et al. 2004]. As indicated by the study results from Azour et al. [2005], individuals with greater lengths and unit weights characterised by high condition and growth rate prevail in the early stages of the round goby's invasion, at their low concentration. This is caused by limited competition for food supplies. With an increase in the concentration of the population in the consecutive stage of expansion, which simultaneously induces food competition and reduction of food supplies, the mean length and weight of the fish, conditions factors and their growth rate decrease.

It has to be emphasises here that statistically significantly greater linear dimensions of male bodies and ages in comparison to females were observed in the population of the round goby in Szczecin Lagoon although the former ones are characterised by a shorter life cycle [Berg 1965; SOKOŁOWSKa, FEY 2011], but they reach puberty at a slower pace [NIKOLSKI 1970]. The oldest males reached the age of $6+$, which contradicts the theory from MARSDEN et al. [1997] that males die soon after reproduction. This is not a sensational phenomenon because fish aged over 6 years were found in populations in Gdansk Bay and in the coastal region of Denmark [Azour 2015; SOKOŁOWSKA, FEY 2011].

\section{CONCLUSIONS}

Currently, the round goby (Neogobius melanostomus) in Szczecin Lagoon became a permanent component of the ecosystem and created a population capable of reproduction, which is indicated by lengths, weights and ages of the caught fish. The condition of the fish indicates that the environmental conditions of this water body are not a deterrent to the presence of this species. In consecutive years, the progressive invasion of the round goby up the Oder River may become a threat to habitats of numerous water animal species in the whole basin. Therefore, permanent monitoring of this species should be performed in the next years in order to estimate the effect of the invasive round goby on habitats of native water animals and correctly forecast changes in the size of its population.

\section{REFERENCES}

Azour F., Deurs M., Behrens J., Carl H., Hussy K., Greisen K., EBERT R., MOLLER P.R. 2015. Invasion rate and population characteristics of the round goby $\mathrm{Neo}-$ gobius melanostomus: Effects of density and invasion history. Aquatic Biology. Vol. 24 p. 41-52.

BERG L.S. 1965. Freshwater fishes of the USSR and adjacent countries. [Translated from Russian]. Jerusalem. Israel Program for Scientific Translations pp. 602.

BorowsKi W. 1999. Babka bycza w Zalewie Wiślanym [The round goby in the Vistula Lagun]. Magazyn Przemysłu Rybnego. $\mathrm{Nr}$ 4(12) p. 39. 
Bøhn T., Sandlund O.T., Amundsen P.A., Primicerio R. 2004. Rapidly changing life history during invasion. Oikos. Vol. 106. Iss. 1 p. 138-150.

Brandner J., Cerwenka A.F., Schliewen U.K., Geist J. 2013. Bigger is better: Characteristics of round gobies forming an invasion front in the Danube River. PLoS ONE. Vol. 8 (9) e0073036. DOI 10.1371/journal.pone. 0073036.

CiepielewSKi W., HoRnATKIEWICZ-ŻBIK A. 2003. Różnorodność ichtiofauny w jeziorach Słowińskiego Parku Narodowego [Diversity of ichthyofauna in Slowinski National Park]. Komunikaty Rybackie Instytutu Rybactwa Śródlądowego. Nr 2 p. 22-26.

CzugaŁA A., WoźniCZKA A. 2010. The River Odra estuary - another Baltic Sea area colonized by the round goby Neogobius melanostomus Pallas, 1811. Aquatic Invasions. Vol. 5. Suppl. 1 p. 61-65. DOI 10.3391/ai.2010. 5.S1.014.

DĄBKowski S.L., WesoŁowski P., BRYsiewicz A., HumiCZEWSKI M. 2017. Międzyodrze: An example of diverse economic and nature-related activities in the part of the Lower Odra Valley. Journal of Water and Land Development. No. 34 p. 117-129. DOI 10.1515/jwld-20170045 .

Grosholz E.D. 1996. Contrasting rates of spread for introduced species in terrestrial and marine systems. Ecology. Vol. 77 p. $1680-1686$.

Grula D., BALÁŽOvÁ M., Copp G.H., KovÁČ W. 2012. Age and growth of invasive round goby Neogobius melanostomus from middle Danube. Cental European Journal of Biology. Vol. 7. Iss. 3 p. 448-459.

GuTOWSKY L.F.G., Fox M.G. 2011. Occupation, body size and sex ratio of round goby (Neogobius melanostomus) in established and newly invaded areas of an Ontario River. Hydrobiologia. Vol. 671. Iss. 1 p. 27-37.

GÜMÜş A., KURT A. 2009. Age structure and growth by otolith interpretation of Neogobius melanostomus (Gobiidae) from Southern Black Sea. Cybium. Vol. 33. Iss. 1 p. 29-37.

Kornis M.S., Mercado-Silva N., VAnder Zanden M.J. 2012. Twenty years of invasion: A review of round goby Neogobius melanostomus biology, spread and ecological implications. Journal of Fish Biology. Vol. 80. Iss. 2 p. $235-285$.

Kostrzewa J., Grabowski M. 2003. Oportunistic feeding strategy as factor promoting the expansion of racer goby (Neogobius gymnotrachelus Kessler, 1857) in the Vistula basin. Lauterbornia. Vol. 48 p. 91-100.

Kottelat M., Freyhof J. 2007. Handbook of European freshwater fishes. Berlin. Kottelat, Cornol and Freyhof. ISBN 2839902982 pp. 646

KUCZYŃSKI J. 1995. Babka krągła N. melanostomus (Pallas 1811) - emigrant z Basenu Pontokaspijskiego w Zatoce Gdańskiej [Round goby N. melanostomus (Pallas 1811) - an emigrant from the Ponto-Caspian Basin in the Gulf of Gdansk]. Bulletin Sea Fish Institute. No. 2 (135) p. $68-71$.

Kullander S.O., Delling B. 2012. Ryggsträngsdjur: strålfeniga fiskar, Chordata: Actinopterygii. Nationalnyckeln till Sveriges flora och fauna [Chordate: finned fishes, Chordata: Actinopterygii]. Uppsala. ArtDatabanken, Sveriges Lantbruksuniversitet. ISBN 9188506800 pp. 517.
Marentette J.R., Wang G., Tong S., Sopinka N.M., TAVES M.D., KoOPS M.A., BALSHINE S. 2011. Laboratory and field evidence of sex-biased movement in the invasive round goby. Behavioral Ecology and Sociobiology. Vol. 65. Iss. 12 p. 2239-2249.

Marsden J.E., Charlebois P.M., Goettel R.G., Wolfe R.K., JUDE D.J., RUDNIKA S. 1997. The round goby, Neogobius melanostomus (Pallas), a review of European and North American literature. Illinois-India Sea Grant Program and Illinois Natural History Survey. INHS Special Publication. No. 20 pp. 76.

NiKOLSKI G.V. 1970. Ichtiologia szczegółowa [Detailed Ichthyology]. Warszawa. PWRiL pp. 545.

Phillips E.C., Washek M.E., Hertel A.W., Niebel B.M. 2003. The round goby (Neogobius melanostomus) in Pennsylvania tributary streams of Lake Erie. Journal of Great Lakes Research. Vol. 29. Iss. 1 p. 34-40.

SAPOTA M.R. 2005. Round goby (Neogobius melanostomus) fish invader in the Gulf of Gdansk - case of species introduction into the Baltic Sea. Hydrobiologia. Vol. 514 p. 219-224.

SAPOTA M.R., SKÓRA K. 2005. Spread of alien (nonindigenous) fish species Neogobius melanostomus in the Gulf of Gdansk (south Baltic). Biological Invasions. Vol. 7 p. $157-164$

Schomaker C., Wolter C. 2014. First record of the round goby Neogobius melanostomus (Pallas, 1814) in the lower River Oder, Germany. BioInvasions Records. Vol. 3. Iss. 3 p. 185-188. DOI 10.3391/bir.2014.3.3.08

SKÓRA K.E. 1997. Report of the working group on introduction and transfers of marine organisms (WGITMO). ICES Annual Science Conference. 84th Statutory Meeting. 27.09.-04.10.1996 Reykjavik, Iceland p. 96-107.

SKÓRA K.E. 2004. Current zoogeographical range of the expansion of Neogobius melanostomus in Poland and in other regions in Europe. [Baltic Sea - Great Lakes Workshop on Aquatic Invasive Species]. [2729.04.2004 Ann Arbor, Michigan].

SkÓRA K.E., StolarsKi J. 1993. New fish species in the Gulf of Gdańsk, Neogobius sp. [cf. Neogobius melanostomus (Pallas 1811)]. Bulletin of the Sea Fisheries Institute. No. 1(128) pp. 83.

SKÓRA K.E., STOLARSKI J. 1996. Neogobius melanostomus (Pallas 1811), a new immigrant species in the Baltic Sea. Proceedings of the $2^{\text {nd }}$ International Estuary Symposium. Gdańsk. 18-22.10.1993. Crangon. Iss. MBC Gdynia p. 101-108.

SOKAL R.R., ROHLF F.J. 2012. Biometry: The principles and practice of statistics in biological research. $4^{\text {th }}$ ed. New York. Freeman. ISBN 0716786044 pp. 937.

SoKoŁowSKa E., FEY D.P. 2011. Age and growth of the round goby Neogobius melanostomus in the Gulf of Gdańsk several years after invasion. Is the Baltic Sea a new Promised Land? Journal of Fish Biology. Vol. 78. Iss. 7 p. $1993-2009$.

Svetovidov A.N. 1964. Ryby Černogo Morja [Fish of Black Sea]. Moskva. Nauka pp. 554.

WIESNER C. 2005. New records of non-indigenous gobies (Neogobius spp.) in the Austrian Danube. Journal of Applied Ichthyology. Vol. 21 p. 324-327.

WINKLER H.M. 2006. Die Fischfauna der südlichen Ostsee [The fish fauna of the southern Baltic Sea]. Meeresangler-Magazin. $\mathrm{Nr} 16$ p. 17-18. 


\section{Przemyslaw CZERNIEJEWSKI, Adam BRYSIEWICZ}

Kondycja i struktura populacji babki byczej (Neogobius melanostomus Pallas, 1811) w Zalewie Szczecińskim w latach 2010-2014

\section{STRESZCZENIE}

Babka bycza (Neogobius melanostomus Pallas) jest jednym z najbardziej inwazyjnych gatunków ryb na świecie, w tym również w Polsce. W latach 2010-2014 z wód Zalewu Szczecińskiego pozyskano 300 os. tego gatunku i wykonano badania struktury wielkościowej, płci i wieku populacji oraz kondycji odłowionych ryb. Średnia długość całkowita ciała $(T L)$ oraz długość ciała $(S L)$ wszystkich złowionych ryb wyniosła odpowiednio $149,2 \mathrm{~mm}( \pm 42,21)$ i $128,1 \mathrm{~mm}( \pm 38,65)$. Struktura wieku złowionych ryb składała się z 9 roczników, z wyraźną dominacją ryb w wieku 3+ i 4+. Wartości średnie współczynników kondycji dla całej próby ryb wyniosły $0,20( \pm 0,02)$, przy czym nie zanotowano różnic istotnych statystycznie w poszczególnych latach (ANOVA, $p>0,05$ ), jakkolwiek kondycja ryb w latach 2010-2011 była nieznacznie lepsza niż w latach 2013-2014. Uzyskane wyniki wskazują, że środowisko Zalewu Szczecińskiego zapewnia osobnikom tego gatunku odpowiednie warunki do życia i można sądzić, iż liczebność osobników tego gatunku będzie się zwiększała.

Słowa kluczowe: babka bycza, Neogobius melanostomus, struktura dlugości, struktura płci, wiek ryb, Zalew Szczeciński 